\title{
PENGEMBANGAN KARAKTER SISWA SEKOLAH DASAR BERBASIS PANCASILA DI ERA REVOLUSI INSDUSTRI 4.0
}

\author{
Nashran Azizan ${ }^{1}$ \\ Maulana Arafat Lubis ${ }^{2}$ \\ 1Mahasiswa Pascasarjana Universitas Negeri Medan \\ 2Dosen PGMI IAIN Padangsidimpuan \\ Corresponding author: nashran_azizan@yahoo.com
}

\begin{abstract}
Abstrak
Karakter merupakan akhlak yang harus ditanamkan kepada siswa agar menjadi makhluk yang bermartabat. Karakter menjadi suatu hal yang tidak dapat dipisahkan dari tujuan pendidikan. Pengembangan karakter harus selalu digalakkan demi terwujudnya masyarakat yang sesuai dengan nilai-nilai Pancasila. Perkembangan zaman yang terus berkembang hingga era revolusi industri 4.0 menjadi tantangan untuk lebih memperhatikan karakter. Indonesia adalah negara yang berlandaskan Pancasila dan Pancasila dijadikan sebagai dasar negara maupun ideologi sehingga bercita-cita mewujudkan rakyat yang aman, tentram, dan damai. Nilai-nilai Pancasila berperan penting dalam kehidupan bangsa. Revolusi industri 4.0 adalah era di mana teknologi menjadi suatu kebutuhan dalam mempermudah setiap pekerjaan, ada hal yang urgen dalam mengembangkan karakter siswa SD dengan cara mengamalkan Pancasila yaitu baik dalam menggunakan media sosial. Hal ini disebabkan seringnya terjadi kegaduhan yang dapat memecahkan NKRI sehingga nilai-nilai Pancasila tidak lagi kokoh. Untuk itu, nilai-nilai Pancasila harus diintegrasikan dalam pembelajaran guna meningkatkan karakter siswa sekolah dasar di era revolusi industri 4.0 .
\end{abstract}

Kata kunci: Karakter Siswa Sekolah Dasar, Pancasila, Revolusi Industri 4.0,

\section{PENDAHULUAN}

Perkembangan zaman yang terus meningkat mengharuskan pendidik terutama bagi guru Sekolah Dasar untuk selalu up to date menyikapi perubahan teknologi yang semakin canggih. Hingga kini, perubahan teknologi sudah mencapai pada tingkat 4.0 yang biasa dikenal dengan revolusi industri. Guru merupakan tombak bagi kecerdasan intelektual maupun spiritual terhadap peserta didik. Untuk menjawab tantangan perubahan teknologi menurut lbda (2018) di abad 21 terjadi kemajuan teknologi bergerak pesat, negara memerlukan Sumber Daya Manusia (SDM) yang memiliki tiga pilar penting yaitu literasi, kompetensi, dan karakter.

Permasalahan yang sering terjadi pada pendidikan yaitu merosotnya karakter peserta didik. Sebagaimana kehidupan yang sekarang berbasis digital, semuanya begitu mudah untuk diakses melalui teknologi. Selama ini banyak peserta didik bebas melakukan apa saja dalam dunia teknologi. Termasuk meng-upload foto-foto yang tidak sesuai dengan etika kehidupan. Budaya malu peserta didik sudah teregradasi sehingga mereka bebas melakukan apa saja pada dunia teknologi.

Begitu hebatnya perubahan teknologi mengubah sikap manusia. Kurangnya sosialisasi terhadap antar teman, antar guru. Karena masing-masing peserta didik sudah banyak yang menggunakan gadget. Sehingga, jarang sekali terjadi komunikasi. Tidak hanya itu, revolusi industri 4.0 dapat membuat peserta didik melupakan nilai-nilai yang terkandung dalam Pancasila. Pancasila bukanlah sebuah teks yang hanya dihapal saja. Melainkan nilai-nilai yang terkandung di dalamnya harus dapat diaplikasikan ke dalam kehidupan nyata. Untuk itu pendidikan salah satu upaya untuk merubah karakter siswa sekolah dasar berbasis Pancasila di era revolusi industri 4.0.

Menurut asmaroini (2017) Kelangsungan hidup negara dan bangsa Indonesia di era globlalisasi, mengharuskan kita untuk melestarikan nilai-nilai Pancasila, agar generasi penerus bangsa tetap dapat menghayati dan mengamalkannya dan agar intisari nilai-nilai yang luhur itu tetap terjaga dan menjadi pedoman bangsa Indonesia sepanjang masa. Pendidikan karakter berbasis Pancasila harus ditanamkan sejak peserta didik duduk dibangku sekolah dasar. Karena pada tahap awal ini peserta didik sangat mudah menerima dan mencontoh apa yang mereka lihat dengan nyata. Untuk itu penanaman nilainilai Pancasila harus diintegrasikan dalam proses pembelajaran sehingga nantinya dapat di aplikasikan oleh peserta didik dalam kehidupan nyata.

Salah satu mata pelajaran yang dapat menanamkan nilai-nilai Pancasila yaitu PKn. Menurut Peraturan Menteri Pendidikan Nasional Nomor 22 Tahun 2006 bahwasanya Pendidikan Kewarganegaraan (PKn) adalah mata pelajaran yang memfokuskan pada pembentukan warga negara yang memahami dan mampu melaksanakan hak-hak dan kewajibannya untuk menjadi warga negara Indonesia yang cerdas, terampil, dan berkarakter yang diamanatkan oleh Pancasila dan UUD 1945. Tidak hanya PKn, mata pelajaran lainnya juga harus memperhatikan nilai-nilai karakter di dalamnya.

Perkembangan kurikulum K-13 (Kurikulum 2013) dimana pada kurikulum tersebut tidak hanya berfokus pada pengetahuan semata, melainkan sikap dan juga keterampilan. Ketiga penilaian ini digunakan untuk semua mata pelajaran. Untuk itu, kerja sama antara guru dan peserta didik sangat diharuskan demi meningkatnya karakter 


\section{PEMBAHASAN}

\section{Karakter Siswa Sekolah Dasar}

Menurut Setiawan, (2017:92) karakter adalah cara berpikir dan berperilaku yang menjadi ciri khas tiap individu untuk hidup dan bekerjasama, baik dalam lingkup keluarga, masyarakat dan negara. Individu yang berkarakter baik adalah jawaban dari akibat yang dibuatnya, (Suyatno : 2009).

Pendidikan karakter adalah pendidikan budi pekerti yang melibatkan aspek pengetahuan (cognitive), perasaan (feeling), dan tindakan (action). Menurut Thomas Lickona dalam Setiawan (2017:92) tanpa ketiga aspek ini, pendidikan karakter tidak akan efektif. Hal ini sejalan dengan penilaian pada kurikulum 2013, dimana aspek yang dinilai yaitu pengetahuan, sikap dan keterampilan. Sebagaimana dalam Undang-undang nomor 20 tahun 2003 tentang Sistem Pendidikan Nasional maka "pendidikan budaya dan karakter bangsa diartikan sebagai proses internalisasi serta penghayatan nilai-nilai budaya dan karakter bangsa yang dilakukan peserta didik secara aktif dibawah bimbingan guru, kepala sekolah dan tenaga kependidikan serta diwujudkan dalam kehidupannya di kelas, sekolah dan masyarakat.

Menurut Puskur (2010) adapun tujuan pendidikan budaya dan karakter yaitu :

a. Mengembangkan potensi afektif peserta didik sebagai manusia dan warganegara yang memiliki nilai-nilai budaya dan karakter bangsa.

b. Mengembangkan kebiasaan dan perilaku peserta didik yang terpuji dan sejalan dengan nilai-nilai universal dan tradisi budaya bangsa yang religius.

c. Menanamkan jiwa kepemimpinan dan tanggungjawab peserta didik sebagai penerus bangsa.

d. Mengembangkan kemampuan peserta didik menjadi manusia yang mandiri, kreatif, berwawasan kebangsaan.

e. Mengembangkan lingkungan kehidupan sekolah sebagai lingkungan belajar yang aman, jujur, penuh kreativitas dan persahabatan, serta dengan rasa kebangsaan yang tinggi dan penuh kekuatan (dignity).

Menyikapi tujuan pendidikan budaya dan karakter yang dikemukakan oleh puskur, tentunya hal ini menjadi perhatian bagi para guru untuk membentuk karakter peserta didik sejak duduk dibangku sekolah dasar. Karakter harus ditanamkan sejak dini, karena masa-masa ini akan lebih mudah diterapkan pada anak. Apalagi untuk anak-anak yang duduk dibangku sekolah dasar, mereka belum terkontaminasi dengan pengaruh globalisasi disamping peran guru, orangtua dan masyarakat yang selalu gigih dalam membimbing dan mendidik mereka.

Pada pembelajaran di sekolah, tentunya guru harus mampu menerapkan strategi ataupun model pembelajaran yang menarik untuk membangun semangat peserta didik dalam belajar. Tujuan guru tidak hanya membuat peserta didik menjadi pintar, melainkan membentuk sikap mereka kearah yang lebih baik lagi. Jika anak sudah memiliki sikap yang baik, ia akan lebih mudah lagi dalam menerima ilmu yang disampaikan pada guru. Guru harus mampu mengemas proses pembelajaran menjadi inovatif. Menurut setiawan (2012) pembelajaran inovatif terdiri dari, pendekatan student centered, multi model dan metode, multimedia, multi sumber belajar, pembelajaran konstekstual, evaluasi yang berbasis kognitif, afektif dan psikomotorik, posisi guru sebagai director of learning. Pembelajaran inovatif dilakukan unuk meningkatkan karakter dan membuat pembelajaran menjadi lebih bermakna.

Dalam menyiapkan pembelajaran, guru juga harus memperhatikan RPP (Rencana Pelaksanaan Pembelajaran) yang berbasis karakter dengan memperhatikan 11 nilai karakter yang dirumuskan oleh Depdiknas (Setiawan, 2012) yang meliputi ketaqwaan, kejujuran, kedisplinan, demokratis, adil, bertanggungjawab, cinta tanah air, orientasi pada keunggulan, gotong royong, menghargai, dan rela berkorban. Ke 11 nilai tersebut harus ada dalam setiap tujuan pelaksanaan pembelajaran agar karakter peserta didik dapat terbentuk.

\section{Nilai-nilai Pancasila}

Pancasila merupakan ideologi bangsa Indonesia. Pancasila bukan hanya sekedar teks yang harus dihapal melainkan makna dari setiap butir kalimat yang mengandung nilai-nilai harus diaplikasikan dalam kehidupan bermasyarakat. Pancasila bukan sekedar lambang burung garuda yang hanya terpampang begitu saja. Pancasila tidak sesederhana itu. Pancasila merupakan pedoman hidup bernegara bagi bangsa Indonesia.

Hariyono (2014) mengatakan bahwa kepentingan bangsa dan Negara selalu menempati posisi yang dominan dalam perumusan Pancasila sebagai dasar Negara maupun sebagai pandangan hidup bangsa. Untuk itu, Pancasila adalah suatu hal yang tidak dapat dipisahkan dalam kehidupan.

Moerdiono dalam Setiawan (2014:130) menunjukkan adanya 3 tataran nilai dalam ideologi Pancasila, yaitu :

1. Nilai dasar, yaitu suatu nilai yang bersifat amat abstrak dan tetap, yang terlepas dari pengaruh perubahan waktu. Nilai dasar Pancasila ditetapkan oleh para pendiri negara. Nilai dasar Pancasila tumbuh baik dari sejarah perjuangan bangsa Indonesia melawan penjajahan yang telah menyengsarakan rakyat, maupun dari cita-cita yang ditanamkan dalam agama dan tradisi tentang suatu masyarakat yang adil dan makmur berdasarkan kebersamaan, pesatuan dan kesatuan seluruh warga masyarakat.

2. Nilai instrumental, yaitu suatu nilai yang bersifat konstektual. Nilai instrumental merupakan penjabaran dari nilai dasar, yang merupakan arahan kinerjanya untuk kurun waktu tertentu dan kondisi tertentu.

3. Nilai praksis, yaitu nilai yang terkandung dalam kenyataan sehari-hari, berupa cara bagaimana rakyat melaksanakan (mengaktualisasikan) nilai Pancasila.

Salah satu hal sederhana yang dapat dilakukan guru untuk mengamalkan nilai Pancasila seperti yang diungkapkan oleh Azizan (2017) Pendidik membiasakan peserta didik berdoa sebelum dan sesudah belajar agar nilai religius yang 
terdapat pada Pancasila bisa menjadi penguat pada peserta didik. Sering kali hal yang khidmat ini dilupakan. Sehingga peserta didik memulai pembelajaran tanpa berdoa.

\section{Revolusi Industri 4.0}

Sejarah revolusi industri dimulai dari industri 1.0, 2.0, 3.0, sampai industri 4.0. fase indsutri merupakan real change dari perubahan yang ada. Industri 1.0 ditandai dengan mekanisasi produksi untuk menunjang efektivitas manusia, industri 2.0 dicirikan oleh produksi massal dan standarisasi mutu, industri 3.0 ditandai dengan penyesuaian massal dan fleksibilitas manufaktur berbasis otomasi dan robot. Industri 4.0 selanjutnya hadir menggantikan industri 3.0 yang ditandai dengan cyber fisik dan kolaborasi manufaktur (Hermann at al, 2015; Irianto, 2017).

Industri 4.0 disebut revolusi digital atau era disrupsi teknologi yang merupakan penggunaan teknologi dari berbagai bidang khususnya pendidikan seperti gadget ataupun smartphone.

Artinya revolusi industri dijadikan sebagai tantangan dan pemanfaatan. Revolusi industri 4.0 dikatakan sebagai tantangan jika penggunaan teknologi disalah gunakan oleh siswa sekolah dasar apabila media sosial seperti Facebook, Whatsapp, youtube, Instagram, dan lain-lain. Realitanya siswa SD di era industri 4.0 sekarang sering memposting kalimatkalimat maupun foto dan video yang tidak baik, hal ini terjadinya degradasi etika dan penyimpangan nilai-nilai Pancasila. Lain halnya pemanfaatan teknologi di era industri 4.0 jika dijadikan sebagai alat bantu dalam proses pembelajaran.

Simpulannya ialah zaman boleh berkembang, sebaik apapun perkembangan zaman tetap jagalah ketegakan nilainilai Pancasila dan tanamkan kepada siswa agar mereka dapat mengamalkannya dalam kehidupan sehari-hari. Jika satu saja nilai Pancasila tidak dilaksanakan maka karakter siswa akan anjlok bahkan tidak lagi memiliki moral

\section{SIMPULAN}

Revolusi Industri 4.0 harus dijadikan sebagai peluang bagi para pendidik khususnya guru dalam meningkatkan kemajuan pendidikan. Pendidikan berbasis digital jangan dijadikan sebagai bencana, melainkan tantangan yang harus dipecahkan dan berusaha untuk menjadikan tantangan ini sebagai peluang dalam pendidikan yang lebih berkompeten terutama dalam meningkatkan karakter siswa sekolah dasar yang berbasis nilai-nilai Pancasila. Kemajuan teknologi harus dimanfaatkan dengan sangat baik dan tetap memperhatikan nilai-nilai Pancasila agar nantinya peserta didik dapat menjadi generasi penerus bangsa yang cerdas, terampil dan berkarakter.

Membentuk karakter siswa sekolah dasar yang berbasis nilai-nilai Pancasila di era revolusi industri 4.0 dapat menjadikan peserta didik menjadi generasi yang akan terus mengindahkan nilai-nilai Pancasila untuk menjadi pedoman bangsa Indonesia sepanjang masa dan tidak tertinggal dengan kemajuan teknologi yang terus berkembang dari waktu ke waktu.

\section{REFERENS}

Asmaroini, Puji Ambiro. 2017. Menjaga Eksistensi Pancasila Dan Penerapannya Bagi Masyarakat Di Era Globalisasi. Jurnal Pancasila dan Kewarganegaraan, Vol. 1 No. 2 Januari 2017.

Azizan, Nashran. 2017. "Penguatan Nilai-nilai Pancasila Pada Peserta Didik di Sekolah Dasar". Makalah disampaikan pada Seminar Nasional Tahunan Fakultas IImu Sosial dengan tema "Pendidikan IImu-ilmu Sosial Berwawasan Kebangsaan. Medan: Hotel Arya Duta Medan 20 Oktober 2017.

Hariyono. 2014. Ideologi Pancasila Roh Progresif Nasionalisme Indonesia. Malang: Intans Publishing.

Hermann, M., Pentek, T., \& Otto, B. 2016. Design Principles for Indistrie 4.0 Scenarios. Presented at the 49th Hawailan International Conference on Systems Science.

Irianto, D. 2017. Indsutry 4.0; The Challenges of Tomorrow. Disampaikan pada Seminar Nasional Teknik Industri, BatuMalang.

Ibda, Hamidulloh. 2018. Penguatan Literasi Baru Pada Guru Madrasah Ibtidaiyah Dalam Menjawab Tantangan Era Revolusi Industri 4.0. Journal Of Research And Thought Of Islamic Education, (Online). Vol.1 No.12018.

Puskur, Balitbang Depdiknas. 2001. Model Pembelajaran IPS Terpadu. Jakarta : tanpa penerbit

Setiawan, Deny. 2017. Pendidikan Kewarganegaraan. Medan : Madenatera.

Setiawan. Deny. 2012. "Pendidikan Kewarganegaraan Berbasis Karakter Melalui Penerapan Pendekatan Pembelajaran Aktif, Kreatif, Efektif, dan Menyenangkan". Makalah disampaikan pada Seminar Internasional dan Konferensi Internasional Pendidikan Dasar dengan tema "Early-Childhood Education: Active, Creative, Joyful. Medan : Universitas Negeri Medan 6-7 Juli 2012.

Setiawan, Deny. 2014. Pendidikan Karakter Dalam Perspektif Kewarganegaraan. Medan : Larispa Indonesia 